\title{
Effects of the seasonal flooding on riparian soil seed bank in the Three Gorges Reservoir Region: a case study in Shanmu River
}

\author{
Miao Zhang ${ }^{1}$, Fangqing Chen ${ }^{1,2^{*}}$, Shaohua Chen ${ }^{2}$, Yajin Wang ${ }^{1}$ and Jianzhu Wang ${ }^{2}$
}

\begin{abstract}
Introduction: The water-level fluctuation in the Three Gorges Reservoir Region has changed dramatically as a result of the hydroelectric project for flood control and power generation. The riparian seasonal hydrological environment also has changed from summer flooding with winter drought to summer drought with winter flooding. The changes of riparian seed bank and vegetation were investigated to determine the effects of the seasonal flooding on the composition and spatial distribution of riparian soil seed bank and the similarity of seed bank to standing vegetation.
\end{abstract}

Case description: We conducted intensive riparian soil sampling (525 samples) along altitude gradient in the Shanmu River, a tributary of the Yangzi River in the reservoir region of China. Seed bank density, species richness and composition of soil seed bank were examined using the seedling-emergence method. The seasonal hydrological conditions resulted in a decrease in species diversity and an increase in the distribution heterogeneity of the soil seed bank. The soil seed bank was composed of 48 species from 22 families and 40 genera. Most species were annual and perennial herbaceous Polygonaceae, Asteraceae, and Poaceae. Rumex dentatus was the predominant species accounting for $27.0 \%$ of the total seeds. Diversity and composition of the seed bank changed along an altitude gradient and soil depth. Maximum species richness was found in the top soil layer at $165 \mathrm{~m}$ and $175 \mathrm{~m}$ above sea level. The mean overall seed density of the soil seed bank was 13,475.3 ind $\mathrm{m}^{-2}$. Density and the number of seeds increased initially and then decreased with increased altitude. Maximum seed density $\left(22,500.2\right.$ ind $\left.\mathrm{m}^{-2}\right)$ was found at $165 \mathrm{~m}$ above sea level in the intermediately flooded riverbank, with the seed number accounting for $27.8 \%$ of the total soil seed bank. Average seed density declined significantly with soil depth. The similarity of seed bank to standing vegetation was relatively high.

Discussion and Evaluation: The environmental heterogeneity created by the wide range and seasonal flooding led to the changes in biodiversity and seed density along altitude gradient. The seasonal flooding also led to the increase in the similarity of seed bank to standing vegetation as their composition both degraded.

Conclusions: The seasonal flooding due to the dam reshape the composition and spatial distribution of riparian soil seed bank and limit the vegetation to a grassland dominated by a few annuals and perennials in the Three Gorges Reservoir Region.

Keywords: Species diversity, Seed density, Spatial distribution, Similarity, Three Gorges Reservoir Region

\footnotetext{
*Correspondence: fangqing1963@hotmail.com

${ }^{1}$ Engineering Research Center of Eco-Environment in the Three Gorges

Reservoir Region, Ministry of Education, China Three Gorges University,

Yichang, China

Full list of author information is available at the end of the article
} 


\section{Background}

The soil seed bank provides a propagule source for the survival, dispersal, and establishment of plant populations playing an important role in vegetation regeneration, recovery and succession (Nathan and Muller-Landau 2000; Yu and Jiang 2003; Farrell et al. 2010). Composition and distribution of seeds reflect the structure of current vegetation and also determine the trend of future vegetation development (Leck 2003; Wang and Zhu 2002). Flooding is a critical ecological process influencing the riparian soil seed bank in wetland areas. It can structure the riparian soil seed bank temporally and spatially and determine seed contribution to extant vegetation (Hölzel and Otte 2001; Capon and Brock 2006). The range, duration and frequency of flooding all influence seed dispersal range and affect species composition and spatial distribution patterns of seed banks (Capon 2007; Hou et al. 2008; Osunkoya et al. 2014), and ultimately determine vegetation development (Battaglia and Collins 2006; Stroh et al. 2013; Su et al. 2012). A dramatic hydrological change can alter and degrade the riparian soil seed bank and vegetation (Hölzel and Otte 2004; Olmstead et al. 2013; Osunkoya et al. 2014). Knowledge of riparian soil seed banks and their response to the variations in water regime is crucial to understanding vegetation restoration, estimating the quality of degraded riparian ecosystems, and analyzing vegetation succession (Beatrijs and Olivier 2008; Wang et al. 2013; Nishihiro et al. 2006).

The water level in the Three Gorges Reservoir Region (TGRR) has reached $175 \mathrm{~m}$ above sea level following the completion of dam construction in 2009. The damming increases the flooding amplitude with up to $35 \mathrm{~m}$, and switches the flooding time from summer to winter (Chen and Xie 2009; Lu et al. 2010b). These variations in water depth and flooding pattern in the reservoir are established to aid both in flood control and hydropower generation. A flooding zone about $400 \mathrm{~km}^{2}$ now occurs in TGRR. The reversal of flooding time, prolonged flooding duration, and new flooding zone (about $400 \mathrm{~km}^{2}$, transferred from terrestrial system) dramatically alter environmental conditions in the riparian zone (New and Xie 2008). Some species have disappeared from river banks as they do not adapt to the environmental changes. The composition and structure of riparian vegetation has significantly degraded (Chen and Xie 2009; Lu et al. 2010a). Wang et al. (2009) and $\mathrm{Lu}$ et al. (2010b) investigated the effects of the initial impoundment (155 m above sea level, in 2008) on the riparian soil seed bank in the reservoir area, and found that flooding significantly decreased species diversity and seed quantity of the soil seed bank. Meanwhile, flooding timing and depth had no effect on species diversity and seed quantity. However, there have been no additional studies since full impoundment (175 $\mathrm{m}$ above sea level) of the reservoir took place in 2009.

We hypothesized that increased flooding reshaped soil seed bank and caused its differentiation among sites with different elevations (flood depth and duration) in the drawdown zone of TGRR. The hypothesis was tested by analyzing the changes of species composition and seed density of soil seed bank along altitude. The objectives of this study were to (1) examine whether the characteristics of riparian soil seed bank, including composition, diversity, seed density and the similarity to standing vegetation differs between flooding zone and no-flooding zone, (2) determine whether the composition, diversity and seed density of riparian soil seed bank differ across sites with different elevations in the drawdown zone, and (3) relate the characteristics of riparian soil seed bank to the environmental changes induced by the seasonal flooding, and discuss the changing trends of vegetation to provide a scientific basis useful for riparian vegetation restoration and management.

\section{Methods \\ Study area}

The study plot was located on the riverbank of the Shanmu River $\left(30^{\circ} 52^{\prime} 22^{\prime \prime}-30^{\circ} 53^{\prime} 17^{\prime \prime} \mathrm{N}, 110^{\circ} 54^{\prime} 05^{\prime \prime}-\right.$ $110^{\circ} 54^{\prime} 28^{\prime \prime} \mathrm{E}$ ) (Fig. 1), a tributary of Yangzi River in Zigui County, TGRR. The regional climate is subtropical continental monsoon with four distinct seasons. Mean annual temperature is approximately $17.9{ }^{\circ} \mathrm{C}$. Mean annual precipitation is $1100 \mathrm{~mm}$ with $80 \%$ of annual precipitation occurring from April to October. The riverbank slope averaged $28^{\circ}$. Soil type was yellow loam with approximately $40 \mathrm{~cm}$ depth. Vegetation before the construction of the dam was a coniferous and deciduous broad leaf forest. This was cleared in 2007 prior to the Three Gorges Dam completion. The current vegetation in the water fluctuation zone is grassland dominated by Cynodon dactylon, $R$. dentatus, and Setaria viridis. The terrestrial vegetation above the water fluctuation zone is a mixed coniferous and deciduous broad leaf forest dominated by Pinus massoniana and Quercus variabilis.

A riverbank with typical riparian vegetation along the Shanmu River was chosen as the field experimental plot. Seven transects were established on the riverbank along an altitude gradient from 150 to $180 \mathrm{~m}$ at $5 \mathrm{~m}$ intervals covering a height of $30 \mathrm{~m}$ riverbank above sea level. The flooding zone is from 150 to $175 \mathrm{~m}$ and the non-flooding zone is from 175 to $180 \mathrm{~m}$. Twenty-five quadrats $\left(1 \times 1 \mathrm{~m}^{2}\right)$ were established randomly in each transect (Fig. 1). The total drawdown zone (145-175 m) experienced five cycles of submersion and subsequent exposure prior to our 2014 field tests. 


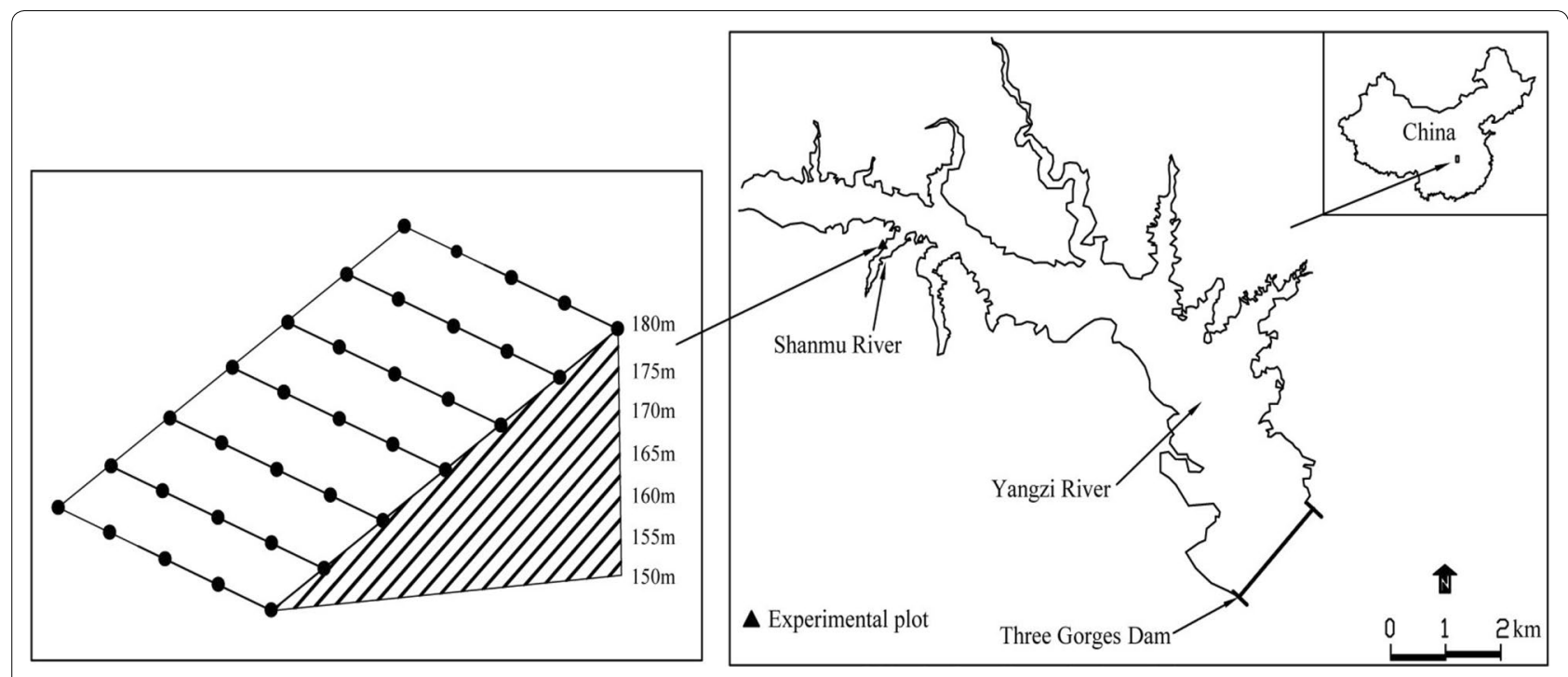

Fig. 1 The location of experimental plot and the distribution of sample transects

\section{Sample collection of soil seed bank}

In May 2014, filed surveys were conducted as soon as the transects were reexposed after waters subsided. Surface vegetation was removed from the quadrats. Soil was sampled randomly in each quadrat using a soil collector (8 cm diam. $\times 16 \mathrm{~cm}$ long). Each soil core was sectioned into three soil depths $(0-5,5-10,10-15 \mathrm{~cm})$ representing the topsoil, mid soil and subsoil layers, respectively. Soil from each section was wrapped in a plastic bag. A total of 525 soil samples were collected at the field experimental plot.

\section{Determination of soil seed bank}

In laboratory, soil samples were air dried in a cool and ventilated location. Rocks, roots, plant and animal residues and other debris in soil samples were removed. Samples were gently crushed with a wooden hammer, and stones and impurities were removed using a $4 \mathrm{~mm}$ sieve. Species and number of seeds in samples was determined using the method of seedling-emergence (Tang et al. 1999; ter Heerdt et al. 1996; Bigwood 1988). Each soil sample was placed into a germination tray $(20 \mathrm{~cm} \times 15 \mathrm{~cm} \times 5 \mathrm{~cm})$, and spread in a $2 \mathrm{~cm}$ deep layer onto a $3 \mathrm{~cm}$ thick layer of sterile sand. The sand substrate was prepared by oven drying at $120^{\circ} \mathrm{C}$ for $12 \mathrm{~h}$. Germination trays were placed in a plant growth chambers, and maintained at $25{ }^{\circ} \mathrm{C}, 75 \% \mathrm{RH}$, and a light:dark cycle of 12:12 h. Soil samples were watered to saturation daily and seedling species were identified at this time. Indentified seedlings were removed to prevent overcrowding, and the seedling number of each species was recorded. Soil was stirred to encourage seed germination in samples where few seeds germinated. The germination experiment continued until no additional seedlings appeared for 2 weeks. The germination trays with unidentified seedlings were move out growth chamber and raised in greenhouse until seedlings were identified. Seeds were classified as annual, perennial herbage, shrub or fluorescence and tree in life form for the composition comparison of soil seed bank.

\section{Data analysis}

Seed number and the seed density of all species in each soil seed bank sample were calculated respectively. The species and seed number of each species in a soil sample included those identified by manual separation and those identified by seedling-emergence. Biodiversity indexes at each altitude and soil layer, including Shannon-Wiener diversity index, Simpson dominance index, Pielou evenness index and Margalef richness index of soil seed bank, were calculated respectively. The characteristics of soil seed bank in composition and spatial distribution were further determined by comparing species composition and life form, and the biodiversity indexes of soil seed bank among different altitudes and soil layers. A univariate analysis was used to evaluate the significance of differences in the quantitative spatial distribution of the soil seed bank. Seed density of soil sample was used as a dependent variable, and altitude gradient and soil depth were used as independent variables respectively. Duncan's multiple range test was used to compare differences between groups when the effect of an independent variable was significant. All analyses were performed using SPSS 17.0.

The relationship of coexisting species in soil seed bank and established vegetation was classified into four types 
Table 1 Seed density of dominant species in the soil seed bank on riverbank

\begin{tabular}{|c|c|c|c|c|c|}
\hline Riverbank & Number & Species & Family & $\begin{array}{l}\left.\text { Seed density (ind } \mathrm{m}^{-2}\right) \\
(\text { mean } \pm \mathrm{SE})\end{array}$ & $\begin{array}{l}\text { Percentage } \\
(\geq 2.50 \%)\end{array}$ \\
\hline \multirow[t]{11}{*}{ Flooding zone } & 1 & Rumex dentatus $\mathrm{L}$. & Polygonaceae & $3626.59 \pm 699.93$ & 27.00 \\
\hline & 2 & Setaria viridis (L.) Beauv & Gramineae & $1447.72 \pm 200.45$ & 10.80 \\
\hline & 3 & Setaria glauca (L.) Beauv & Gramineae & $1227.44 \pm 385.89$ & 9.10 \\
\hline & 4 & Solanum nigrum L. & Asteraceae & $1036.36 \pm 309.44$ & 7.70 \\
\hline & 5 & Digitaria ciliaris (Retz.) Koel. & Gramineae & $912.95 \pm 233.46$ & 6.80 \\
\hline & 6 & Paspalum distichum $\mathrm{L}$. & Gramineae & $769.64 \pm 267.28$ & 5.70 \\
\hline & 7 & Memorialis hirta (B1.) Wedd. & Urticaceae & $559.98 \pm 140.85$ & 4.20 \\
\hline & 8 & Gnaphalium affine D. Don & Asteraceae & $541.40 \pm 120.26$ & 4.00 \\
\hline & 9 & Oxalis corniculata L. & Oxalidaceae & $522.82 \pm 83.26$ & 3.90 \\
\hline & 10 & Cyperus iria L. & Cyperaceae & $444.53 \pm 168.90$ & 3.30 \\
\hline & 11 & Phyllanthus urinaria $\mathrm{L}$. & Euphorbiaceae & $395.44 \pm 80.41$ & 2.90 \\
\hline \multirow[t]{12}{*}{ Non-flooding zone } & 1 & Cyperus iria L. & Cyperaceae & $1608.28 \pm 1510.73$ & 16.90 \\
\hline & 2 & Memorialis hirta (B1.) Wedd. & Urticaceae & $1242.04 \pm 610.96$ & 13.10 \\
\hline & 3 & Gnaphalium affine D. Don & Asteraceae & $899.68 \pm 518.07$ & 9.50 \\
\hline & 4 & Oxalis corniculata L. & Oxalidaceae & $875.80 \pm 93.36$ & 9.20 \\
\hline & 5 & Setaria viridis (L.) Beauv & Gramineae & $796.18 \pm 251.46$ & 8.40 \\
\hline & 6 & Trigonotis peduncularis (Trev.) Benth. & Boraginaceae & $692.68 \pm 160.52$ & 7.30 \\
\hline & 7 & Rubus phoenicolasius Maxim. & Rosaceae & $573.25 \pm 214.60$ & 6.00 \\
\hline & 8 & Digitaria ciliaris (Retz.) Koel. & Gramineae & $501.59 \pm 192.82$ & 5.30 \\
\hline & 9 & Artemisia argyi H. Lév. \& Vaniot & Asteraceae & $445.86 \pm 309.23$ & 4.70 \\
\hline & 10 & Viola betonicifolia J. E. Smith & Violaceae & $429.93 \pm 231.58$ & 4.50 \\
\hline & 11 & Phyllanthus urinaria $\mathrm{L}$. & Euphorbiaceae & $414.02 \pm 80.21$ & 4.40 \\
\hline & 12 & Setaria glauca (L.) Beauv & Gramineae & $262.74 \pm 128.13$ & 2.80 \\
\hline
\end{tabular}

as Whipple (1978): A high percentage both in soil bank and vegetation, $B$ high percentage in vegetation, low percentage in seed bank, $C$ high percentage in seed bank, low percentage in vegetation, $\mathrm{D}$ low percentage both in soil bank and vegetation. The number of each type was used to analyze the change of similarity between the flooding zone and non-flooding zone.

\section{Results}

\section{Species diversity of the soil seed bank and spatial}

\section{distribution}

Forty-eight plant species from 22 families and 40 genera were identified from the soil seed bank in the fluctuation zone. The dominant families include Asteraceae (12 species), Gramineae (8 species) and Polygonaceae (3 species) (Table 1). There were 15 species whose seed number each accounted for more than $1.0 \%$ of the total soil seed bank. These species include $R$. dentatus, Solanum nigrum and $S$. viridis. Among them, $R$. dentatus had the maximum seed density ( 3626.59 ind $\mathrm{m}^{-2}$ ). Its seed number accounted for $27.0 \%$ of the total soil seed bank. There were 12 species whose seed number each accounted for $<0.01 \%$ of the total soil seed bank. Cyperus difformis had the lowest seed density $\left(1.33\right.$ ind $\mathrm{m}^{-2}$ ). In contrast, there were 32 species in 18 families and 28 genera in the riverbank non-flooding zone. Asteraceae and Gramineae had 6 and 5 species respectively. Cyperus iria had the maximum seed density (1608.28 ind $\mathrm{m}^{-2}$ ), accounting for $16.9 \%$ of the total soil seed bank.

Species from the soil seed bank were mainly annuals. The percentage of annual plants ranged from 61.9 to $81.8 \%$ meanwhile perennial herbage from 14.8 to $28.6 \%$, shrubs and vines from 0 to $9.7 \%$ and trees from 0 to $6.2 \%$, respectively (Table 2 ). Species diversity changed with altitude in the fluctuation zone. Altitudes 165 and $175 \mathrm{~m}$ had the maximum species number. Altitude $170 \mathrm{~m}$ had the highest evenness, diversity index and dominance index and $175 \mathrm{~m}$ had the highest richness index (Table 3). Species diversity also changed with soil layer. The highest richness index, diversity index and dominance index occurred at topsoil, but subsoil had the highest evenness index (Table 4).

\section{Quantitative characteristics of soil seed bank and spatial distribution}

Average seed density of the soil seed bank was $13,475.3$ ind $\mathrm{m}^{-2}$ in the fluctuation zone, which was greater than that in the non-flooding zone. The 
Table 2 Life form composition of the soil seed bank at different altitudes on riverbank

\begin{tabular}{|c|c|c|c|c|c|c|c|}
\hline Life form & $150 \mathrm{~m}$ & $155 \mathrm{~m}$ & $160 \mathrm{~m}$ & $165 \mathrm{~m}$ & $170 \mathrm{~m}$ & $175 \mathrm{~m}$ & $180 \mathrm{~m}$ \\
\hline A (\%) & 81.8 & 61.9 & 71.4 & 71.9 & 81.5 & 68.8 & 64.5 \\
\hline B (\%) & 18.2 & 28.6 & 21.4 & 18.8 & 14.8 & 18.8 & 25.8 \\
\hline C (\%) & - & 9.5 & 7.1 & 6.3 & 3.7 & 6.2 & 9.7 \\
\hline D (\%) & - & - & & 3.1 & - & 6.2 & - \\
\hline
\end{tabular}

$A$, annual; $B$, perennial herbage; $C$, shrub or fluorescence; $D$, tree; -, no occurrence

Table 3 The changes of diversity indices of the soil seed bank with altitude gradient

\begin{tabular}{llllll}
\hline Altitude $(\mathbf{m})$ & Species number & Margalef index & Simpson index & Shannon-Wiener index & Pielou index \\
\hline 150 & 22 & 2.122 & 0.866 & 2.399 & 0.776 \\
155 & 21 & 1.955 & 0.800 & 2.045 & 0.672 \\
160 & 28 & 2.483 & 0.828 & 2.284 & 0.686 \\
165 & 32 & 2.665 & 0.842 & 2.256 & 0.651 \\
170 & 27 & 2.251 & 0.900 & 2.595 & 0.787 \\
175 & 32 & 2.727 & 0.868 & 2.428 & 0.701 \\
180 & 31 & 2.786 & 0.911 & 2.694 & 0.785 \\
\hline
\end{tabular}

Table 4 Diversity indices of the soil seed bank in different soil layers

\begin{tabular}{lclllll}
\hline Types & Soil layer $(\mathbf{c m})$ & Species number & Margalef index & Simpson index & Shannon-Wiener index & Pielou index \\
\hline Flooding zone & $0-5$ & 42 & 3.296 & 0.891 & 2.654 & 0.710 \\
& $5-10$ & 34 & 2.851 & 0.859 & 2.447 & 0.694 \\
Non-flooding zone & $10-15$ & 30 & 2.705 & 0.886 & 2.582 & 0.759 \\
& $0-5$ & 26 & 2.444 & 0.901 & 2.540 & 0.780 \\
& $5-10$ & 18 & 1.837 & 0.878 & 2.416 & 0.836 \\
& $10-15$ & 22 & 2.279 & 0.906 & 2.594 & 0.839 \\
\hline
\end{tabular}

Table 5 Change of seed density of seed bank with altitude gradient

\begin{tabular}{llll}
\hline Riverbank & Altitude $(\mathbf{m})$ & Seed density (ind $\mathbf{~}^{\mathbf{2}}$ ) (mean \pm SE) & Percentage (\%) \\
\hline Flooding zone & 150 & $3972.9 \pm 409.4 \mathrm{~d}$ & 4.9 \\
& 155 & $5637.0 \pm 811.1 \mathrm{~d}$ & 7.0 \\
& 160 & $10,660.9 \pm 1959.7 \mathrm{c}$ & 13.2 \\
& 165 & $22,500.2 \pm 6998.4 \mathrm{a}$ & 27.8 \\
& 170 & $20,812.1 \pm 3295.1 \mathrm{ab}$ & 25.7 \\
Non-flooding zone & 175 & $17,269.1 \pm 3537.5 \mathrm{~b}$ & 21.4 \\
Fvalue; Sig. & 180 & $9562.1 \pm 2066.7 \mathrm{~cd}$ & - \\
\hline
\end{tabular}

The letters following the seed density indicate the level of difference among altitudes at $\mathrm{P}<0.05$

** The mean difference is significant at the 0.01 level

quantitative distribution of the riparian soil seed bank changed significantly with altitude gradient in the fluctuation zone $(\mathrm{P}<0.01)$ (Table 5$)$. The maximum seed density $\left(22,500.2 \pm 6998.4\right.$ ind $\left.\mathrm{m}^{-2}\right)$ occurred at $165 \mathrm{~m}$, where the seed number accounted for $27.8 \%$ of the total soil seed bank. Seed density within the soil seed banks decreased with increasing and decreasing altitude. The seed density at the lower fluctuation zone was lower 
Table 6 Changes of seed density in soil seed bank with soil layers

\begin{tabular}{llll}
\hline Riverbank & $\begin{array}{l}\text { Soil layer } \\
(\mathbf{c m})\end{array}$ & $\begin{array}{l}\text { Seed density (ind } \\
\mathbf{m}^{\mathbf{2}} \text { ) } \text { (mean } \pm \text { SE) }\end{array}$ & Percentage (\%) \\
\hline Flooding zone & $0-5$ & $8426.2 \pm 1243.4 \mathrm{a}$ & 62.5 \\
& $5-10$ & $3540.3 \pm 753.2 \mathrm{~b}$ & 26.3 \\
& $10-15$ & $1505.4 \pm 266.8 \mathrm{~b}$ & 11.2 \\
& & $17.375 ; 0.000^{* *}$ & - \\
F value; Sig. & $0-5$ & $5501.6 \pm 1527.1 \mathrm{a}$ & 57.5 \\
$\begin{array}{l}\text { Non-flooding } \\
\text { zone }\end{array}$ & $5-10$ & $2054.1 \pm 698.8 \mathrm{~b}$ & 21.5 \\
& $10-15$ & $2006.4 \pm 120.5 \mathrm{~b}$ & 21.0 \\
& & $4.251 ; 0.000^{* *}$ & - \\
\hline
\end{tabular}

Different letters following the seed density indicate significant difference among soil layers at $\mathrm{P}<0.05$

** The mean difference is significant at the 0.01 level

than that at the upper fluctuation zone. The minimum seed density $\left(3972.9 \pm 409.4\right.$ ind $\mathrm{m}^{-2}$ ) occurred at $150 \mathrm{~m}$.

The quantitative distribution of the soil seed bank differed significantly among soil layers $(\mathrm{P}<0.01)$ (Table 6$)$. Most seeds were distributed in the $0-5 \mathrm{~cm}$ deep topsoil. The average seed density of the soil seed bank in the topsoil was 8426.2 ind $\mathrm{m}^{-2}$, and the seed number accounted for $62.5 \%$ of the total seed bank. Soil seed bank density decreased with soil depth declining to 3540.3 and 1505.4 ind $\mathrm{m}^{-2}$ at soil depths of $5-10$ and $10-15 \mathrm{~cm}$, respectively. The vertical distribution of the soil seed bank at $180 \mathrm{~m}$ the non-flooding zone showed a pattern similar to that of the fluctuation zone. However, the percentage differences among the topsoil, middle soil and subsoil on the non-flooding zone were lower than that of the fluctuation zone.

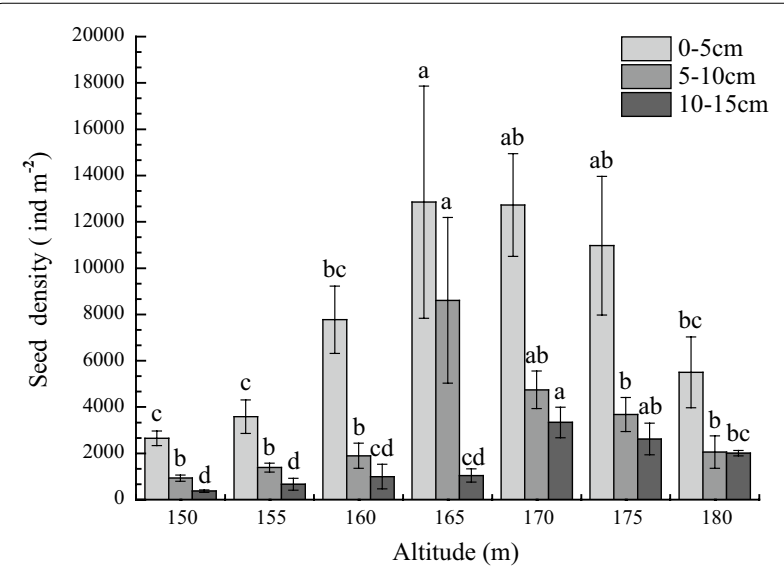

Fig. 2 Changes in seed density of the soil seed bank with altitude and soil depth. Different letters above columns indicate significant difference among soil layers at $P<0.05$
The vertical distribution pattern of the riparian soil seed bank varied with altitude. The seed density in topsoil was greater than that in the mid soil and subsoil. The maximum seed density of the soil seed bank in topsoil, middle soil and subsoil appeared at 165 and $170 \mathrm{~m}$ respectively (Fig. 2). However, each dominant species had its spatial distribution pattern (Fig. 3). Mazus japonicus was restricted to the middle and low flooding zone, so were Gnaphalium affine to the middle and upon flooding zone. S. viridis, meanwhile, distributed on all flooding zone.

The similarity of soil seed bank to established vegetation In the flooding zone, there were 30 species coexisting both in soil and vegetation, 33 and 18 species only in vegetation and soil, respectively. The similarity index of seed bank to standing vegetation was about 0.531 . In the nonflooding zone, by contrast, 19 species occurred both in soil and vegetation, 36 and 12 species only in vegetation and soil seed bank with relative low similarity index 0.223 (Table 7).

The relationship of coexisting species in soil seed bank and established vegetation differentiated on the Shanmu River riverbank. There were 10 type A species, 6 type B species, 6 type $C$ species and 8 type D species representing by Setaria glauca, Artemisia argyi, Trigonotis peduncularis and Senecio scandens, respectively, on the flooding zone. However, only 7 type A species, 4 type B species, 5 type $C$ species and 3 type $D$ species appeared on the non-flooding zone. There were more coexisting and dominant species in seed bank and vegetation on the flooding zone which increased their similarity (Fig. 4).

\section{Discussion}

Flooding has significant influences on seed sources which further determine species composition of the riparian soil seed bank (Leck 2003; Peterson and Baldwin 2004). Nicol et al. (2003) studied the influence of water regime on seed bank composition and found that seed compositions were correlated with the water regime and independent of the initial seed bank composition irrespective of differences in the initial seed bank composition. The construction of the Three Gorges Dam altered the flooding regime in the reservoir from summer submersion-winter exposure to summer exposure-winter submersion to improve flood control and power generation. Seasonal timing of inundation stressed riparian plant growth and flowering (Greet et al. 2013). The average duration of flooding along the altitude gradients from 150 to $175 \mathrm{~m}$ ranged from 240 to 30 days (Wang and Gao 2010). With the seasonal flooding, only a small number of annuals and a few flood-tolerant perennials were able to complete their life cycle and produce seeds during the limited exposure 


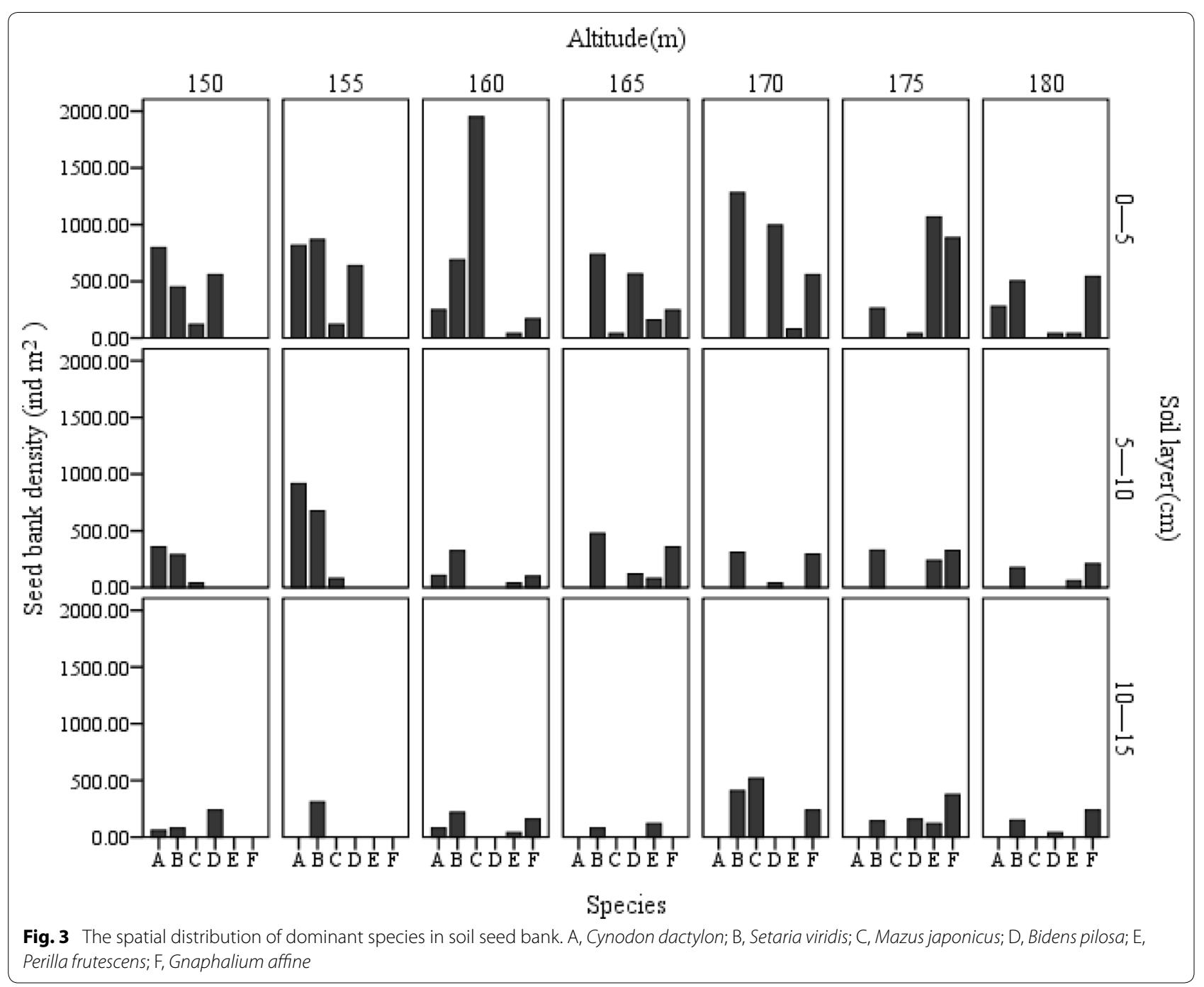

Table 7 Similarity of riparian soil seed bank to standing vegetation

\begin{tabular}{lllllll}
\hline Riverbank & $\begin{array}{l}\text { Total species } \\
\text { in vegetation }\end{array}$ & $\begin{array}{l}\text { Total species } \\
\text { in seed bank }\end{array}$ & $\begin{array}{l}\text { Species only } \\
\text { in vegetation }\end{array}$ & $\begin{array}{l}\text { Species only } \\
\text { in seed bank }\end{array}$ & $\begin{array}{l}\text { Coexisting } \\
\text { species }\end{array}$ & $\begin{array}{l}\text { Similarity } \\
\text { index }\end{array}$ \\
\hline Flooding zone & 63 & 48 & 33 & 18 & 30 & 0.531 \\
Non-flooding zone & 55 & 31 & 36 & 12 & 19 & 0.223 \\
\hline
\end{tabular}

time, especially at the lower altitude. Our field investigation indicated that the standing riparian vegetation along the Shanmu River was composed of 63 species. Among these species, seeds of 33 species were not present in the riparian soil seed bank. The species composition of the riparian soil seed bank along the Shanmu River was simplified and mainly consisted of selected annuals accounting for $68.8 \%$ of the total species number.
The change of species composition in the soil seed bank differed among different impoundment periods in the TGRR. During the primary impoundment, species composition in the soil seed bank was relatively complex and included the seeds produced by standing vegetation. The survival of seeds produced by vegetation before impoundment was dominated by annuals and the dominant species in this vegetation included perennials, 


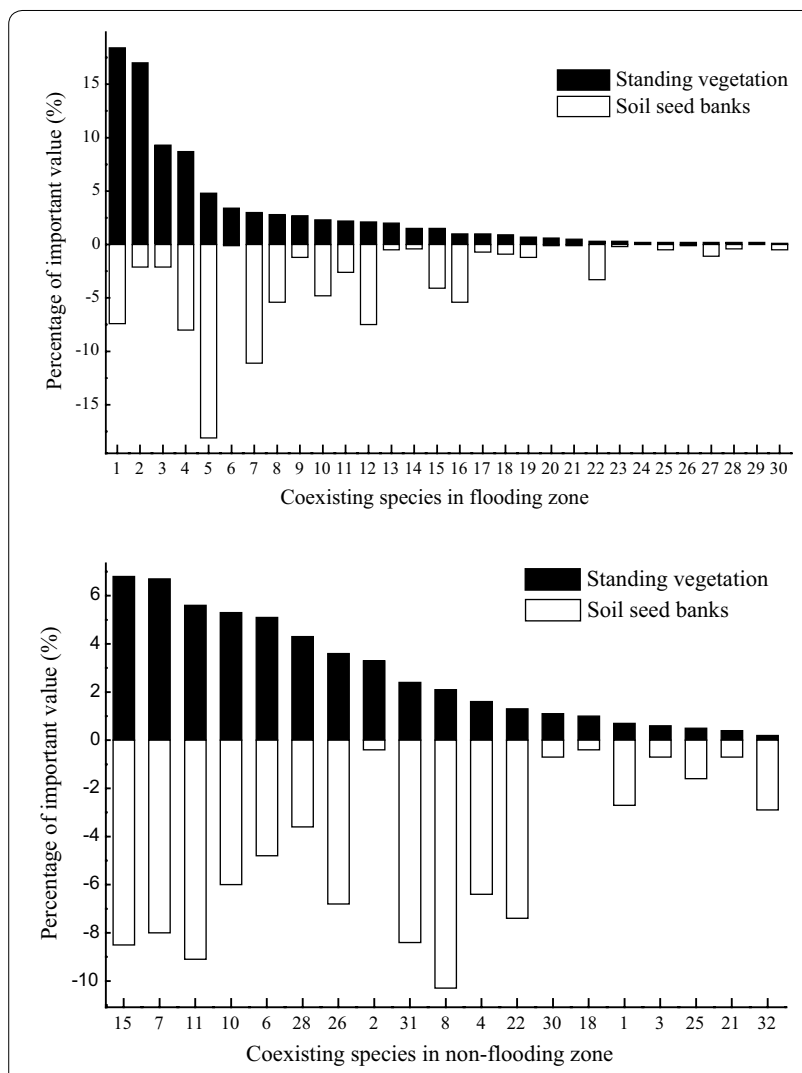

Fig. 4 The percentage of important value accounting for by the coexisting species in seed bank and vegetation on the riverbank. 1, Setaria glauca; 2, Cynodon dactylon; 3, Bidens frondosa; 4, Digitaria ciliaris; 5, Rumex dentatus; 6, Artemisia argyi; 7, Setaria viridis; 8, Hyrtanandra; 9, Polygonum hydropiper; 10, Phyllanthus urinaria; 11, Cyperus iria; 12, Solanum nigrum; 13, Xanthium sibiricum; 14, Bidens pilosa; 15, Gnaphalium affine; 16, Paspalum distichum; 17, Mazus japonicus; 18, Eclipta prostrata; 19, Acalypha australis; 20, Youngia japonica; 21, Phytolacca acinosa; 22, Trigonotis peduncularis; 23, Aeschynomene indica; 24, Polygonum aviculare; 25, Magnolia multiflora; 26, Rubus phoenicolasius; 27, Stellaria media; 28, Viola betonicifolia; 29, Senecio scandens; 30, Glochidion wilsonii; 31, Oxalis corniculata; 32, Cyperus rotundus

annuals and shrubs (Wang et al. 2009; Lu et al. 2010b). Our results indicated that species composition of the soil seed bank was further simplified after a long period of water level fluctuation. Many pre-dam riparian shrub and perennial species disappeared from the riparian soil seed bank. The soil seed bank was dominated by some annuals and a few flooding-tolerant perennials.

Flooding also affects seed dispersing and deposing from standing and surrounding vegetation, and influenced species distribution in the riparian soil seed bank (Boedeltje et al. 2004; Xiao et al. 2011; Alves Pagotto et al. 2011; Hayashi et al. 2012). The timing of seed dispersal and river flow interact to determine the annual composition of species cohorts (Dixon 2003). Species groups segregated on the basis of exposure length of sediments to air, rate of drawdown, and the water depth (Nicol et al. 2003; $\mathrm{Xu}$ et al. 2007). The maximal species richness of riparian seed bank appeared where vegetation had the most species (Calcada et al. 2015). Species diversity of the riparian soil seed bank varied with the altitude gradient along the Shanmu River. The maximum diversity appeared at the intermediately flooded zone, while the least diversity was found at the lower riverbank. Intermediate diversity occurred at the upper fluctuation zone. Exposure and fluctuation times in the middle upper fluctuation zone coincided with seed maturity of many plant species allowing this zone a relatively greater opportunity to receive air and water-dispersed seeds.

The diversity distribution of the soil seed bank differed among soil layers. The top soil layer had the highest richness and dominance index and subsoil had the highest evenness. A potential mechanism causing this trend is because all of the dispersed seeds were first deposited on the top soil layer. The soil seed bank on the terrestrial zone had the same spatial distribution as the fluctuation zone. But the difference between topsoil and subsoil was relatively small, indicating that water-level fluctuations and submersion did not favor seed deposition into deeper soil layers.

The intensity, duration, and frequency of water-level fluctuations significantly influence distribution of the riparian soil seed bank (Weiterova 2008; Liu et al. 2006). The season and time that seeds, dispersed by wind and flow, fall on the riverbank changed with altitude because water-level fluctuations affect submersion and exposure times of riverbank areas (Peterson and Baldwin 2004). This also resulted in spatial heterogeneity in quantitative composition of plants within the soil seed bank (Yuan et al. 2007; James et al. 2007; Nielsen et al. 2012). Under the influence of this seasonal flooding, the submersion and exposure seasons of the riverbank changed with altitude gradient and shaped the quantitative spatial distribution of the riparian soil seed bank (Wang et al. 2009). Wang et al. (2010) and Lu et al. (2010b) found that the primary impoundment in TGRR led to the decrease in seed density of the soil seed bank in the fluctuation zone. The average seed density was about 12,667 and 4578 ind $\mathrm{m}^{-2}$, respectively. However, differences among altitudes were not significant. Our results indicated that a new quantitative distribution pattern of soil seed bank was formed after a lengthy water-level fluctuation period in TGRR. The average seed density in the soil seed bank on the Shanmu River riverbank was $16,517.0$ ind $\mathrm{m}^{2}$. The highest seed bank density and total seed number appeared at $165 \mathrm{~m}$ (the middle upper fluctuation zone). This exposed area and fluctuation time coincided with the summer and autumn seed maturation periods of 
many plant species, providing significant opportunities to receive air and water-dispersed seeds. In contrast, the lower fluctuation zone was only exposed and fluctuated during summer. The short exposure time limited seed availability and reduced the seed density of the soil seed bank to a low level. The upper fluctuation zone was exposed for the longest time, and had ample time to receive seeds dispersed by air. However, the water fluctuations at this location in winter were at an inappropriate time for seed spread by water. Thus, the seed density and seed number of the soil seed bank at the lower and upper flooding zone were relatively low.

The environmental heterogeneity of soil also contributed to quantitative distribution variation of the soil seed bank. Anoxia resulting from submersion and drought stress can both decrease seed vitality (Riddin and Adams 2009). The seasonal flooding created moisture, temperature, and oxygen soil conditions at the middle upper riverbank favorable for seed survival. In contrast, the lower riverbank was stressed by lengthy submersion, and the upper riverbank was stressed by prolonged drought.

Water-level fluctuations caused spatial differences in seed density among soil layers in the soil seed bank. Seed density of the soil seed bank decreased with soil depth as seeds in the subsoil generally came from the infiltration of seeds in the top soil layer. The quantity of infiltrated seeds decreased with soil depth. Initial seed quantity in the topsoil and soil depth both determined seed distribution in the subsoil. Decreases in altitude and soil depth caused the decrease of seed viability as the soil oxygen, moisture and temperature became less favorable (Chen and Xie 2009; Carta et al. 2013).

The composition and biodiversity of seed bank determine the similarity of seed bank to established vegetation (Wilson et al. 1993; Xiao et al. 2011). James et al. (2007) suggested that the similarity increased when soil seed bank was mainly composed of annual herbs hereabouts, but decreased when mainly composed of perennial herbs, shrub and trees. There were significant differences in species composition and dominant species between the soil seed bank and the surrounding vegetation during the primary impoundment in the TGRR (Wang et al. 2009; Lu et al. 2010b). The similarity of seed bank to vegetation was relatively low, but increased as a result of the seasonal flooding (Wang et al. 2010). Our results suggested that long-term seasonal flooding further induced the composition of seed bank simple, which increased the similarity index of seed bank to established vegetation.

The soil seed bank may contribute to plant community dynamics following disturbance (Plassmann et al. 2009; Liu et al. 2009). The seasonal flooding caused the degradation of soil seed bank and vegetation on the river bank in the TGRR. Most perennials and woody plants disappeared from seed bank and vegetation, and the soil seed bank was mainly composed of annuals and a few flooding-tolerant perennials. Lu et al. (2010b) investigated the effects of initial impoundment on the riparian soil seed bank and suggested that low species compositional similarity to established vegetation and the dominance of annual plants limited the efficacy of the soil seed bank to restore pre-dam vegetation in the drawdown zone of the TGRR. Our study indicates that the differences in species composition and dominant species between the soil seed bank and surrounding vegetation decreased, implying the vegetation composition and structure gradually stabilized after a long period of water-level fluctuation. The composition of the soil seed bank and vegetation included annuals, perennials and shrubs and vines that differed from the pre-dam riparian soil seed bank and vegetation. The dominant species of the soil seed bank, including selected annuals and several submersion-tolerant perennials, such as $C$. dactylon and $P$. paspaloides, was related to the standing vegetation.

\section{Conclusion}

Under the influence of seasonal flooding, the soil seed bank degraded and was mainly composed of annuals differing significantly from the pre-dam soil seed bank and standing vegetation. The environmental heterogeneity created by the wide range and seasonal flooding led to the changes in biodiversity and seed density along altitude gradient. Maximum species richness and seed density occurred at $165 \mathrm{~m}$ above sea level. The seasonal flooding also increased the similarity of seed bank to established vegetation as both of the composition degraded. The dominant species of the soil seed bank, including selected annuals and several submersion-tolerant perennials, such as $C$. dactylon and $P$. paspaloides, was related to the standing vegetation. It is concluded that the seasonal flooding due to the damming determine the composition and spatial distribution of seed bank and limit the riparian vegetation to a grassland dominated by annuals and perennials in the TGRR.

\footnotetext{
Authors' contributions

$\mathrm{MZ}$ and FC contributed equally to this paper. MZ carried out the experiment, $\mathrm{MZ}$ and FC performed the statistical analyses and drafted the manuscript. YW, SC and JW assisted in the experiment. All authors read and approved the final manuscript.

Author details

${ }^{1}$ Engineering Research Center of Eco-Environment in the Three Gorges Reservoir Region, Ministry of Education, China Three Gorges University, Yichang, China. ${ }^{2}$ International Center for Ecological Protection and Management in the Three Gorges Area, Hubei Province, China Three Gorges University, Yichang, China.
} 


\section{Acknowledgements}

This thesis was financially supported by the National Natural Science Foundation of China (51379105).

\section{Competing interests}

The authors declare that they have no competing interests.

Received: 19 October 2015 Accepted: 7 April 2016

Published online: 21 April 2016

\section{References}

Alves Pagotto M, de Moraes Lima Silveira R, Nunes da Cunha C et al (2011) Distribution of Herbaceous Species in the soil seed bank of a flood seasonality area, Northern Pantanal, Brazil. Int Rev Hydrobiol 96:149-163. doi:10.1002/iroh.201111315

Battaglia LL, Collins BS (2006) Linking hydroperiod and vegetation response in Carolina bay wetlands. Plant Ecol 184:173-185. doi:10.1007/ s11258-005-9062-7

Beatrijs B, Olivier H (2008) Can the seed bank be used for ecological restoration? An overview of seed bank characteristics in European communities. J Veg Sci 19:875-884. doi:10.3170/2008-8-18462

Bigwood DW (1988) Spatial pattern analysis of seed banks: an improving method and optimizing sampling. Ecology 69:497-507. doi:10.2307/1940448

Boedeltje G, Bakker JP, Ten Brinke A et al (2004) Dispersal phenology of hydrochorous plants in relation to discharge, seed release time and buoyancy of seeds: the flood pulse concept supported. J Ecol 92:786-796. doi:10.1111/j.0022-0477.2004.00906.x

Calcada EA, Lenoir J, Plue J et al (2015) Spatial patterns of water-deposited seeds control plant species richness and composition in riparian forest landscapes. Landsc Ecol. doi:10.1007/s10980-015-0236-y

Capon SJ (2007) Effects of flooding on seedling emergence from the soil seed bank of a large desert floodplain. Wetlands 27:904-914. doi:10.1672/0277-5212(2007)27[904:EOFOSE]2.0.CO;2

Capon SJ, Brock MA (2006) Flooding, soil seed bank dynamics and vegetation resilience of a hydrologically variable desert floodplain. Freshw Biol 51:206-223. doi:10.1111/j.1365-2427.2005.01484.x

Carta A, Bedini G, Müller JV (2013) Comparative seed dormancy and germination of eight annual species of ephemeral wetland vegetation in a Mediterranean climate. Plant Ecol 214:339-349. doi:10.1007/ s11258-013-0174-1

Chen FQ, Xie ZQ (2009) Survival and growth responses of Myricaria laxiflora seedlings to summer flooding. Aquat Bot 90:333-338. doi:10.1016/j. aquabot.2008.12.006

Dixon MD (2003) Effects of flow pattern on riparian seedling recruitment on sandbars in the Wisconsin River, Wisconsin, USA. Wetlands 23:125-139. doi:10.1672/0277-5212(2003)023

Farrell JM, Murry BA, Leopold DJ et al (2010) Water-level regulation and coastal wetland vegetation in the upper St. Lawrence River: inferences from historical aerial imagery, seed banks, and Typha dynamics. Hydrobiologia 647:127-144. doi:10.1007/s10750-009-0035-z

Greet J, Cousens RD, Webb JA (2013) Seasonal timing of inundation affects riparian plant growth and flowering: implications for riparian vegetation composition. Plant Ecol 214:87-101. doi:10.1007/ s11258-012-0148-8

Hayashi H, Shimatani Y, Shigematsu K et al (2012) A study of seed dispersal by flood flow in an artificially restored floodplain. Landsc Ecol Eng 8:129-143. doi:10.1007/s11355-011-0154-3

Hölzel N, Otte A (2001) The impact of flooding regime on the soil seed bank of flood-meadows. J Veg Sci 12:209-218. doi:10.2307/3236605

Hölzel N, Otte A (2004) Inter-annual variation in the soil seed bank of floodmeadows over two years with different flooding patterns. Plant Ecol 174:279-291. doi:10.1023/B:VEGE.0000049108.04955.e2

Hou ZY, Xie YH, Yu XY (2008) Research method, content, and prospecting seed bank of fresh water wetland. Chin J Ecol 27:1400-1405

James CS, Capon SJ, White MG et al (2007) Spatial variability of the soil seed bank in a heterogeneous ephemeral wetland system in semi-arid Australia. Plant Ecol 190:205-217. doi:10.1007/s11258-006-9201-9
Leck MA (2003) Seed-bank and vegetation development in a created tidal freshwater wetland on the Delaware River, Trenton, New Jersey, USA. Wetlands 23.310-343 doi:10.1672/9-20

Liu GH, Liu YP, Li W (2006) Small-scale heterogeneity in seed bank of a freshwater marsh. Acta Ecol Sin 26:2739-2743. doi:10.3321/j. issn:1000-0933.2006.08.042

Liu WZ, Zhang QF, Liu GH (2009) Seed banks of a river-reservoir wetland system and their implications for vegetation development. Aquat Bot 90:7-12. doi:10.1016/j.aquabot.2008.04.014

Lu ZJ, Li LF, Huan HD et al (2010a) Preliminary effects of impounding on vegetation in drawdown zone of the Three Gorges Reservoir Region. J Wuhan Bot Res 28:303-314

Lu ZJ, Li LF, Jiang MX et al (2010b) Can the soil seed bank contribute to revegetation of the draw down zone in the Three Gorges Reservoir Region? Plant Ecol 209:153-165

Nathan R, Muller-Landau HC (2000) Spatial patterns of seed dispersal, their determinants and consequences for recruitment. Trends Ecol Evol 15:278-285. doi:10.1016/S0169-5347(00)01874-7

New T, Xie ZQ (2008) Impacts of large dames on riparian vegetation: applying global experience to the case of China's Three Gorges Dam. Biodivers Conserv 17:3149-3163. doi:10.1007/s10531-008-9416-2

Nicol JM, Ganf GG, Pelton GA (2003) Seed banks of a southern Australian wetland: the influence of water regime on the final floristic composition. Plant Ecol 168:191-205. doi:10.1023/A:1024430919811

Nielsen DL, Podnar K, Watts RJ et al (2012) Empirical evidence linking increased hydrologic stability with decreased biotic diversity within wetlands. Hydrobiologia 708:81-96. doi:10.1007/s10750-011-0989-5

Nishihiro J, Nishihiro MA, Washitani I (2006) Assessing the potential for recovery of lakeshore vegetation: species richness of sediment propagule banks. Ecol Res 21:436-445. doi:10.1023/A:1025548518991

Olmstead VG, Webb EB, Johnson RW (2013) Moist-soil seed biomass and species richness on Wetland Reserve Program Easements in the Mississippi alluvial Valley. Wetlands 33:197-206. doi:10.1007/s13157-012-0367-8

Osunkoya OO, Ali S, Perrett TNC, Adkins S et al (2014) Soil seed bank dynamics in response to an extreme flood event in a riparian habitat. Ecol Res 29:1115-1129. doi:10.1007/s11284-014-1198-2

Peterson JE, Baldwin AH (2004) Seedling emergence from seed banks of tidal freshwater wetlands: response to inundation and sedimentation. Aquat Bot 78:243-254. doi:10.1016/j.aquabot.2003.10.005

Plassmann K, Brown N, Jones MLM et al (2009) Can soil seed banks contribute to the restoration of dune slacks under conservation management? Appl Veg Sci 12:199-210. doi:10.1111/j.1654-109X.2009.01014.x

Riddin T, Adams JB (2009) The seed banks of two temporary open/ closed estuaries in South Africa. Aquat Bot 90:328-332. doi:10.1016/j. aquabot.2008.12.003

Stroh PA, Mountford JO, Araya YN et al (2013) Quantifying soil hydrology to explain the development of vegetation at an ex-arable wetland restoration site. Wetlands 33:311-320. doi:10.1007/s13157-013-0385-1

Su XL, Zeng B, Huang WJ (2012) Effects of the Three Gorges Dam on preupland and preriparian drawdown zones vegetation in the upper watershed of the Yangtze River, P. R. China. Ecol Eng 44:123-127. doi:10.1016/j. ecoleng.2012.03.001

Tang Y, Cao M, Zhang JH et al (1999) Relationship between soil seed bank and aboveground vegetation in tropical forest of Xishuangbanna. Chin J Appl Ecol 10:279-282

ter Heerdt GNJ, Verweij GL, Bekker RM et al (1996) An improved method for seed-bank analysis: seedling emergence after removing the soil by sieving. Funct Ecol 10:144-151. doi:10.2307/2390273

Wang X, Gao XM (2010) Effects of simulated submergence on seed germination of four common annual herbs in the Three Gorges Reservoir Region, China. Acta Phytoecol Sin 12:1404-1413

Wang ZW, Zhu TC (2002) The seed bank features and its relations to the established vegetation following flooding disturbance on Songnen Steppe. Acta Ecol Sin 22:1392-1398. doi:10.3321/j.issn:1000-0933.2002.09.004

Wang XR, Cheng RM, Feng XH et al (2009) Characteristics of soil seed banks in backwater area of Three Gorges Reservoir water level fluctuating zone at initial stage of river-flooding. Chin J Appl Ecol 20:2891-2897

Wang XR, Cheng RM, Xiao WF et al (2010) Relationship between standing vegetation and soil seed bank in water-level-fluctuating Zone of Three Gorges Reservoir at the beginning after charging water. Acta Ecol Sin 30:5821-5831 
Wang YC, Jiang DM, Toshio O et al (2013) Recent advances in soil seed bank research. Contemp Probl Ecol 6:520-524. doi:10.1134/ S1995425513050181

Weiterova I (2008) Seasonal and spatial variance of seed bank species composition in an oligotrophic wet meadow. Flora 203:204-214. doi:10.1016/j. flora.2007.03.003

Whipple SA (1978) The relationship of buried, germinating seeds to vegetation in an old-growth Colorado subalpine forest. Can J Bot 56:1505-1509. doi:10.1139/b78-176

Wilson MSD, Moore DRJ, Keddy PA (1993) Relationships of marsh seed banks to vegetation patterns along environmental gradients. Freshw Biol 29:361-370. doi:10.1111/j.1365-2427.1993.tb00770.x
Xiao C, Liu WZ, Liu GH (2011) Comparison of the established vegetation and soil seed bank of tidal flat versus tributary habitats of China's Danjiangkou Reservoir: the potential of hydrochory. Chin J Plant Ecol 35:247-255

Xu HL, Li JM, Wang ZR (2007) Spatial distribution characteristics of soil seed bank in lower reaches of Tarim River. J Soil Water Conserv 21:183-186

Yu SL, Jiang GM (2003) The research development of soil seed bank and several hot topics. Acta Phytoecol Sin 27:552-560

Yuan LY, Liu GH, Li W (2007) Seed bank variation along a water depth gradient in a subtropical lakeshore marsh, Longgan Lake, China. Plant Ecol 189:127-137. doi:10.1007/s11258-006-9170-z

\section{Submit your manuscript to a SpringerOpen ${ }^{\circ}$ journal and benefit from:}

- Convenient online submission

- Rigorous peer review

- Immediate publication on acceptance

- Open access: articles freely available online

- High visibility within the field

- Retaining the copyright to your article 